\title{
ВЛИЯНИЕ ФУНКЦИОНАЛЬНОЙ ДОБАВКИ АКТИВИРОВАННОГО УГЛЯ НА КАЧЕСТВО ХЛЕБОБУЛОЧНОГО ИЗДЕЛИЯ
}

E.A. Zenina, E.N. Efremova

\section{THE EFFECT OF FUNCTIONAL ADDITIVES OF THE ACTIVATED COAL ON THE QUALITY OF BAKERY PRODUCTS}

\begin{abstract}
Зенина Елена Анатольевна - канд. с.-х. наук, доц. каф. перерабатывающих технологий и продовольственной безопасности Волгоградского государственного аграрного университета, г. Волгоград. E-mail: lenzsara@mail.ru
\end{abstract}

Ефремова Елена Николаевна - канд. с.-х. наук, доц. каф. перерабатывающих технологий и продовольственной безопасности Волгоградского государственного аграрного университета, г. Волгоград. E-mail: elenalob@rambler.ru

Цель исследования - повышение потребительского спроса хлебобулочных изделий путем расширения ассортимента. Задачи исследования: изучить рецептуру хлебобулочных изделий с добавлением активированного угля; исследовать влияние добавления активированного угля на качество хлебобулочных изделий; рассчитать экономическую эфрфрективность производства хлебобулочного изделия с предлагаемой добавкой. На базе ФГБОУ ВО Волгоградский ГАУ в 2018-2019 ге. проводили пробные выпечки батона пшеничного с добавлением активированного угля. По всем показателям пшеничный батон с активированным углем соответствовал требованиям ГОСТ. Пробную выпечку батона проводили безопарным способом. Описана технология производства пшеничного батона с активированным углем. По отдельности замешивали "белое» пшеничное тесто и "черное» тесто с активированным углем. Выпекали изделия при температуре 180-230 ० $\mathrm{C}$ в течение 25-30 мин. В лаборатории ФГБОУ ВО Волгоградский ГАУ после выпечки проводили анализ качества готовой продукции по ГОСТ 5667-65. Проводили оценку органолептических (вкус, цвет, запах и др.) и физико-химических (влажность, пористость и кислотность) показателей батона
Zenina Elena Anatolyevna - Cand. Agr. Sci., Assoc. Prof., Chair of Processing Technologies and Food Security, Volgograd State Agrarian University, Volgograd.

E-mail: lenzsara@mail.ru

Efremova Elena Nikolaevna - Cand. Agr. Sci., Assoc. Prof., Chair of Processing Technologies and Food Security, Volgograd State Agrarian University, Volgograd.

E-mail: elenalob@rambler.ru

пшеничного и батона с активированным углем. По всем показателям батон с активированным углем имел более высокие показатели: ивет - черный; пористость - развитая, без уплотнений, крупная, тонкостенная и среднеравномерная; эластичность - хорошая; вкус с приятным ароматом; запах - ароматный. По показателям выпечки качество батона с добавлением активированного угля было лучше по фризико-химическим показателям. Мякиш отмечался эластичностью. Пищевая ценность в 100 г продукта батона с добавлением активированного угля: белки - 8,1 2; жиры 4,0; углеводы - 49,9 г. Энергетическая ценность - 268 ккал. Уровень рентабельности производства батона пшеничного с добавлением активированного угля составил 30,6 \%, что на 5,1\% больше уровня рентабельности производства батона пшеничного. Считаем целесообразным введение активированного угля в рецептуру батона пшеничного в качестве функциональной добавки, придающей батону диетические свойства.

Ключевые слова: пшеничный батон, активированный уголь, сорбент, безопарный способ, брожение, формовка, органолептические свойства, пористость, мякиш. 
The research objective was satisfying increased consumers' demand for bakery products by the expansion of their range. The research problems were to study the formulation of bakery products with the addition of activated carbon; to investigate the influence of addition of activated carbon on the quality of bakery products; to calculate economic efficiency of the production of the bakery product with offered additive. On the basis of FSBEI HE Volgograd SAU in 2018-2019 test baking of a long loaf of activated carbon, wheat with its addition was carried out. On all indicators wheat long loaf with activated carbon conformed to the requirements of State Standard. Test baking was carried out by loaf straight dough method. The production technology of a wheat long loaf with activated carbon was described. Separately "white" wheat dough and "black" dough with activated carbon were kneaded. The products were baked at the temperature of 180-230 degrees Centigrade within 25-30 min. In Volgograd SAU laboratories after baking the analysis of the quality of finished goods according to the State Standard 5667-65 was carried out. The assessment of organoleptic (taste, color, smell, etc.) and physical and chemical (humidity, porosity and acidity) indicators of wheat long loaf and a long loaf with activated carbon was carried out. In all indicators the long loaf with activated carbon had higher indicators: color - black; the porosity - developed without consolidations, large, thin-walled and sredneravnomerny; elasticity - good; taste - with pleasant flavor; smell - fragrant. In baking indicators the quality of a long loaf with addition of activated carbon was better according to physical and chemical indicators. The crumb was noted by elasticity. Nutrition value in $100 \mathrm{~g}$ of the long loaf product with addition of activated carbon: proteins $8.1 \mathrm{~g}$; fats - 4.0; carbohydrates - $49.9 \mathrm{~g}$. Power value was $268 \mathrm{kcal}$. The level of profitability of production of wheat long loaf with activated carbon made $30.6 \%$ that is $5.1 \%$ more than the level of profitability of production of wheat long loaf. The introduction of activated carbon to formulation of wheat long loaf is considered to be expedient as functional additive giving to the long loaf dietary properties.

Keywords: wheat long loaf, activated carbon, sorbent, straight dough method, fermentation, molding, organoleptic properties, porosity, crumb.
Введение. В настоящее время основной задачей хлебопекарной промышленности является увеличение ассортимента хлебобулочных изделий и повышение их качества путем введения нового вида дополнительного сырья и пищевых добавок с целью сбалансированного питания людей [1].

В результате анализа фрактического питания в различных регионах нашей страны был сделан вывод о том, что рацион российского населения характеризуется чрезмерным потреблением животных жиров и легко усваиваемых углеводов. Но в то же время для большинства россиян диета недостаточна для потребления полиненасыщенных жирных кислот, макро- и микроэлементов [2]. Отсутствие таких питательных веществ и биологически активных веществ в рационе человека может привести к снижению резистентности человеческого организма к неблагоприятным условиям окружающей среды, повышенному риску заболевания, ухудшению качества жизни и эфффективности терапевтических мер [3].

Основным условием сохранения и укрепления здоровья нации является обеспечение населения безопасными продуктами высокого качества. Поэтому неотложной задачей, стоящей перед специалистами пищевой промышленности, является увеличение минеральной, витаминной и биологической ценности хлебобулочных изделий [4].

Цель исследования: повышение потребительского спроса хлебобулочных изделий путем расширения ассортимента.

Для достижения этой цели были решены задачи: разработать рецептуру пшеничного батона с добавлением активированного угля; исследовать влияние добавления активированного угля на качество хлебобулочных изделий; рассчитать экономическую эфффективность производства хлебобулочного изделия с предлагаемой добавкой.

Объектом исследования являются хлебобулочные изделия.

Методы исследования. Нормативной базой исследования было законодательство Российской Федерации о стандартизации и сертификации, нормативные документы (ГОСТы, ТУ).

Для сохранения и укрепления здоровья наших граждан предприятия разрабатывают ре- 
цептуры и внедряют новые продукты питания. В последнее время в традиционную рецептуру вводится сырье для обогащения хлебобулочных изделий [5]. На базе ФГБОУ ВО Волгоградского ГАУ в 2018-2019 гг. проводили пробные выпечки батона пшеничного с добавлением активированного угля. Уголь активированный - черный порошок или гранулят без вкуса и запаха, полученный путем термической обработки растительного сырья. В пищевой промышленности зарегистрирован как пищевая добавка E153. В настоящее время является пищевым красителем, разрешенным в ЕС во всех продуктах питания. Активированная форма угля обладает адсорбционными свойствами, также этап активации помогает удалить возможные примеси.

Результаты исследования. За основу приготовления батона с активированным углем взяли рецептуру и режим изготовления батона пшеничного (табл. 1).

Рецептура батона пшеничного с добавлением активированного угля

Таблица 1

\begin{tabular}{|l|c|c|}
\hline \multicolumn{1}{|c|}{ Сырьё } & Батон пшеничный & $\begin{array}{c}\text { Батон пшеничный } \\
\text { с активированным углем }\end{array}$ \\
\hline Мука пшеничная, в/с, кг & 100 & 100 \\
\hline Дрожжи сухие, кг & 2,5 & 2,5 \\
\hline Соль, кг & 2,5 & 2,5 \\
\hline Сахар-песок, кг & 3,5 & 3,5 \\
\hline Активированный уголь, в/с, кг & - & 1,0 \\
\hline Масло растительное, л & 8,5 & 8,5 \\
\hline Вода, л & 80 & 80 \\
\hline Время брожения, мин & 45 & 45 \\
\hline
\end{tabular}

Приготовление батона пшеничного и батона с активированным углем проводили безопарным способом. По отдельности замешивали «белое» пшеничное тесто и «черное» тесто с активированным углем. Выпекали изделия при температуре $180-230{ }^{\circ} \mathrm{C}$ в течение 25-30 мин (рис. 1). В лаборатории ФГБОУ ВО Волгоградского ГАУ после выпечки проводили анализ качества готовой продукции по ГОСТ 5667-65 [6].
Проводили оценку органолептических (вкус, цвет, запах и др.) и физико-химических (влажность, пористость и кислотность) показателей батона пшеничного и батона с активированным углем (табл. 2) [7, 8].

Качество батона оценивали не ранее 3 ч после выпечки, но не дольше чем через 24 ч. Образцы булочных изделий хранили при температype $18 \pm 3^{\circ} \mathrm{C}$.

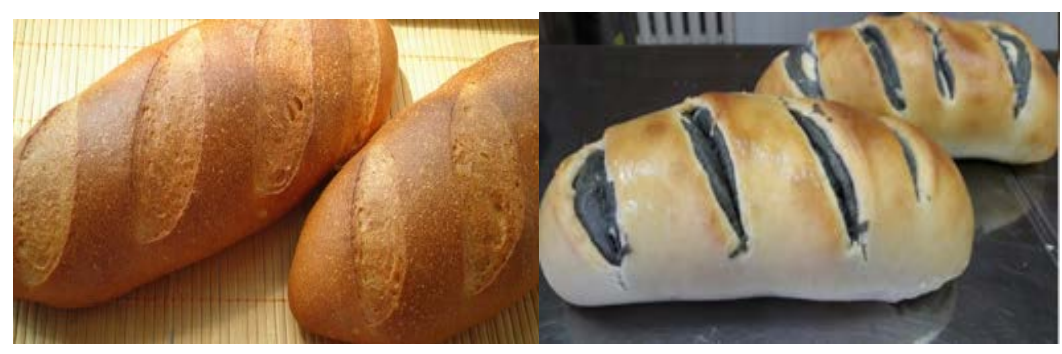

A

Pис. 1. Внешний вид готового изделия: $A$ - пшеничный батон; 5 - пшеничный батон с активированным уелем 
Органолептические показатели батона пшеничного

\begin{tabular}{|c|c|c|}
\hline Показатель & Батон пшеничный & $\begin{array}{c}\text { Батон пшеничный } \\
\text { с активированным углем }\end{array}$ \\
\hline \multicolumn{3}{|c|}{ Внешний вид } \\
\hline Форма & \multicolumn{2}{|c|}{ Соответствует хлебной форме, правильная } \\
\hline Поверхность & $\begin{array}{c}\text { Шероховатая с выпуклой } \\
\text { верхней коркой }\end{array}$ & $\begin{array}{c}\text { Шероховатая с выпуклой } \\
\text { верхней коркой }\end{array}$ \\
\hline Цвет & Соломенно-желтый & Черный \\
\hline \multicolumn{3}{|c|}{ Состояние мякиша } \\
\hline Пропеченность & $\begin{array}{c}\text { Пропеченный, мягкий, } \\
\text { заминающийся }\end{array}$ & $\begin{array}{c}\text { Пропеченный, не липкий, } \\
\text { заминающийся }\end{array}$ \\
\hline Пористость & $\begin{array}{c}\text { Средняя развитая, без пустот, } \\
\text { с уплотнениями, равномерная, } \\
\text { тонкостенная }\end{array}$ & $\begin{array}{l}\text { Развитая, без уплотнений, крупная, } \\
\text { тонкостенная, среднеравномерная }\end{array}$ \\
\hline Эластичность & Средняя & Хорошая \\
\hline Промес & \multicolumn{2}{|c|}{ Без комочков } \\
\hline Вкус & Норма & С приятным ароматным вкусом \\
\hline Запах & Норма & Ароматный \\
\hline
\end{tabular}

Батон с активированным углем по органолептическим показателям имел более высокие показатели: цвет - черно-белый; пористость развитая, без уплотнений, крупная, тонкостенная и среднеравномерная; эластичность - хо- рошая; вкус - с приятным ароматом; запах ароматный. Батон пшеничный по фризикохимическим показателям соответствует требованиям (табл. 3).

\section{Физико-химические показатели батона пшеничного}

\begin{tabular}{|l|c|c|}
\hline \multicolumn{1}{|c|}{ Показатель } & Батон пшеничный & Батон пшеничный с активированным углем \\
\hline Влажность мякиша, \% & 43,0 & 42,0 \\
\hline Кислотность, град. & 3,0 & 2,9 \\
\hline Пористость мякиша, \% & 70,0 & 78,0 \\
\hline
\end{tabular}

По показателям выпечки качество батона с добавлением активированного угля было лучше по физико-химическим показателям. Мякиш отмечался эластичностью. Пищевая ценность в 100 г продукта батона с добавлением активированного угля: белки - 8,1 г; жиры - 4,0; углеводы - 49,9 г. Энергетическая ценность - 268 ккал.

Добавление активированного угля положительно сказалось на подъеме теста. Мякиш батона с добавлением активированного угля обладал высокой пористостью. Добавление активированного угля снижает токсичность муки, загрязненной пестицидами. Внесение активированного угля в батон оказывает благоприятное действие и придает приятный ароматный привкус.

Экономическая эфффективность производства обуславливается такими показателями, как прибыль и уровень рентабельности производства. В таблице 4 рассчитаны затраты на сырье $[9,10]$. 


\section{Затраты на сырье для производства батона пшеничного и батона пшеничного с активированным углем}

\begin{tabular}{|c|c|c|c|c|}
\hline \multirow[b]{2}{*}{ Сырье } & \multirow[b]{2}{*}{$\begin{array}{c}\text { Цена за } 1 \text { кг, } \\
\text { руб. }\end{array}$} & \multirow[b]{2}{*}{$\begin{array}{l}\text { Расход сырья } \\
\text { на } 100 \text { кг муки }\end{array}$} & \multicolumn{2}{|c|}{ Стоимость сырья, руб. } \\
\hline & & & $\begin{array}{c}\text { Батон } \\
\text { пшеничный }\end{array}$ & $\begin{array}{c}\text { Батон пшеничный } \\
\text { с активированным углем }\end{array}$ \\
\hline $\begin{array}{l}\text { Мука пшеничная } \\
\text { высший сорт, кг }\end{array}$ & 11,0 & 100 & 1100 & 1100 \\
\hline Дрожжи сухие, кг & 15,0 & 2,5 & 37,5 & 37,5 \\
\hline Соль, кг & 6,50 & 2,5 & 16,25 & 16,25 \\
\hline Сахар-песок, кг & 26,0 & 3,5 & 91 & 91 \\
\hline $\begin{array}{l}\text { Масло } \\
\text { растительное, л }\end{array}$ & 50 & 8,5 & 425 & 425 \\
\hline Вода, л & 0,017 & 80 & 1,36 & 1,36 \\
\hline $\begin{array}{l}\text { Активированный } \\
\text { уголь, кг }\end{array}$ & 70 & 1,0 & 0 & 70 \\
\hline Итого & - & - & 1671,11 & 1741,11 \\
\hline
\end{tabular}

Затраты на сырье из расчета на 100 кг муки составили: для пшеничного батона - 1671,11 руб., для пшеничного батона с активированным углем - 1741,11 руб. Рост затрат на сырье связан с внесением в рецептуру активированного угля.
Затраты на производство пшеничного батона и батона с активированным углем рассчитаны в таблице 5. 


\section{Экономическая эффрективность производства батона пшеничного и батона с активированным углем}

\begin{tabular}{|l|c|c|}
\hline \multicolumn{1}{|c|}{ Показатель } & Батон пшеничный & Батон пшеничный с активированным углем \\
\hline Выход продукции, кг & 125,0 & 126,7 \\
\hline $\begin{array}{l}\text { Прогнозируемый объем произ- } \\
\text { веденной и реализованной } \\
\text { продукции, шт. }\end{array}$ & 250 & 250 \\
\hline $\begin{array}{l}\text { Затраты на производство го- } \\
\text { товой продукции всего, руб. }\end{array}$ & 4084,11 & 4154,11 \\
\hline В т. ч. сырье, руб. & 1671,11 & 1741,11 \\
\hline $\begin{array}{l}\text { Себестоимость 1 ед. готовой } \\
\text { продукции, руб. }\end{array}$ & 16,34 & 16,62 \\
\hline $\begin{array}{l}\text { Цена реализации } \\
1 \text { ед. продукции, руб. }\end{array}$ & 20,50 & 21,70 \\
\hline $\begin{array}{l}\text { Прибыль от продаж, руб.: } \\
\text { на 1 ед. готовой продукции } \\
\text { всего }\end{array}$ & 4,16 & 5,08 \\
\hline Рентабельность продукции, \% & 1040 & 1270 \\
\hline
\end{tabular}

Стоимость продуктов функционального питания выше стоимости обычных продуктов. Несмотря на увеличение себестоимости батона с активированным углем, прибыль от его продажи на единицу продукции составила 5,08 руб. (на 0,92 руб. больше контрольного варианта). Уровень рентабельности батона пшеничного с добавлением активированного угля составил $30,6 \%$, что на 5,1 \% больше уровня рентабельности батона пшеничного. Данный рост рентабельности произошел за счет незначительного увеличения цены реализации на 5,85 \% и составил 21,7 руб. за 1 ед. изделия. Данный рост цены никак не повлиял на потребительский спрос.

Заключение. Введение активированного угля в рецептуру батона пшеничного целесообразно в качестве функциональной добавки, придающей хлебобулочным изделиям диетические свойства. Такой хлеб может быть использован в лечебно-профилактическом питании.

Добавка активированного угля в рецептуру производства хлебобулочного изделия увеличило экономическую эффективность производства, при этом наблюдался рост рентабельности продукции на 5,1\%.

\section{Литература}

1. Калмыкова Е.В., Ефремова Е.Н. Переработка натурального растительного сырья и использование его в качестве добавок при производстве хлебобулочных изделий // Известия Нижневолжского агроуниверситетского комплекса: наука и высшее профессиональное образование. 2013. № 4 (32). C. 172-177.

2. Батура Н.Г., Типсина Н.Н. Изучение влияния злаковых хлопьев на качество хлебобулочных изделий // Вестник КрасГАУ. 2019. № 12 (153). С. 169-175.

3. Ефрремова Е.Н., Таранова Е.С., Зенина Е.А. Влияние нетрадиционного сырья на качество хлебобулочного изделия // Актуальные направления научных исследований в АПК: от теории к практике: мат-лы национальной науч.-практ. конф. Волгоград: ВолГАУ, 2017. C. 136-141.

4. Сухова О.В., Гордеева В.Ф. Разработка рецептуры хлебобулочного изделия повышенной пищевой ценности // Молодой ученый. 2015. № 9. С. 304-307.

5. Трубина И.А., Скорбина Е.А. Использования адаптогенов растительного происхождения в технологии хлебобулочных изде- 
лий // Современные ресурсосберегающие инновационные технологии производства и переработки сельскохозяйственной продукции в СКФО: сб. науч. ст. 78-й науч.-практ. конф. Ставрополь, 2014. С. 135-138.

6. ГОСТ 5667-65. Хлеб и хлебобулочные изделия. Правила приемки, методы отбора образцов, методы определения органолептических показателей и массы изделий. М.: Стандартинформ, 2006. 4 c.

7. Зенина Е.А., Шершнев А.А., Ефремова Е.Н. Экономическая эффективность производства пшеничного хлеба с функциональной добавкой // Бизнес. Образование. Право. 2019. № 1 (46). С. 165-169.

8. Ефремова Е.Н. Совершенствование рецептуры пшеничного хлеба добавками, обладающими функциональными и технологическими свойствами // Известия Нижневолжского агроуниверситетского комплекса: наука и высшее профессиональное образование. 2015. № 4 (40). С. 207-213.

9. Ефрремова Е.Н., Зенина Е.А., Кузнецова Е.А. и др. Экономическое обоснование производства хлебобулочных изделий с использованием нетрадиционного сырья // Бизнес. Образование. Право. 2018. № 4 (45). С. 102-107.

10. Гупанова Ю.Е. Организационно-экономический механизм управления качеством продукции хлебопекарной промышленности // Эксперт. Пищевая промышленность. 2008. № 8. С. 7-9.

\section{Literatura}

1. Kalmykova E.V., Efremova E.N. Pererabotka natural'nogo rastitel'nogo syr'ja i ispol'zovanie ego $v$ kachestve dobavok pri proizvodstve hlebobulochnyh izdelij // Izvestija Nizhnevolzhskogo agrouniversitetskogo kompleksa: nauka i vysshee professional'noe obrazovanie. 2013. № 4 (32). S. 172-177.

2. Batura N.G., Tipsina N.N. Izuchenie vlijanija zlakovyh hlop'ev na kachestvo hlebobulochnyh izdelij // Vestnik KrasGAU. 2019. № 12 (153). S. 169-175.
3. Efremova E.N., Taranova E.S., Zenina E.A. Vlijanie netradicionnogo syrja na kachestvo hlebobulochnogo izdelija // Aktual'nye napravlenija nauchnyh issledovanij v APK: ot teorii k praktike: mat-ly nacional'noj nauch.-prakt. konf. Volgograd: VolGAU, 2017. S. 136-141.

4. Suhova O.V., Gordeeva V.F. Razrabotka receptury hlebobulochnogo izdelija povyshennoj pishhevoj cennosti // Molodoj uchenyj. 2015. № 9. S. 304-307.

5. Trubina I.A., Skorbina E.A. Ispol'zovanija adaptogenov rastitel'nogo proishozhdenija $v$ tehnologii hlebobulochnyh izdelij // Sovremennye resursosberegajushhie innovacionnye tehnologii proizvodstva i pererabotki sel'skohozjajstvennoj produkcii v SKFO: sb. nauch. st. 78-j nauch.-prakt. konf. Stavropol', 2014. S. 135-138.

6. GOST 5667-65. Hleb i hlebobulochnye izdelija. Pravila priemki, metody otbora obrazcov, metody opredelenija organolepticheskih pokazatelej i massy izdelij. M.: Standartinform, 2006. $4 \mathrm{~s}$.

7. Zenina E.A., Shershnev A.A., Efremova E.N. Jekonomicheskaja jeffektivnost' proizvodstva pshenichnogo hleba s funkcional'noj dobavkoj // Biznes. Obrazovanie. Pravo. 2019. № 1 (46). S. 165-169.

8. Efremova E.N. Sovershenstvovanie receptury pshenichnogo hleba dobavkami, obladajushhimi funkcional'nymi i tehnologicheskimi svojstvami // Izvestija Nizhnevolzhskogo agrouniversitetskogo kompleksa: nauka i vysshee professional'noe obrazovanie. 2015. № 4 (40). S. 207-213.

9. Efremova E.N., Zenina E.A., Kuznecova E.A. i dr. Jekonomicheskoe obosnovanie proizvodstva hlebobulochnyh izdelij s ispol'zovaniem netradicionnogo syr'ja // Biznes. Obrazovanie. Pravo. 2018. № 4 (45). S. 102-107.

10. Gupanova Ju.E. Organizacionno-jekonomicheskij mehanizm upravlenija kachestvom produkcii hlebopekarnoj promyshlennosti // Jekspert. Pishhevaja promyshlennost'. 2008. № 8. S. 7-9. 